\title{
RESOLUÇÃO DE CONFLITOS AMBIENTAIS INTERNACIONAIS: SOBERANIA, JURISDIÇÃO INTERNACIONAL E INGERÊNCIA ECOLÓGICA*
}

\section{RESOLUTION OF INTERNATIONAL ENVIRONMENTAL CONFLICTS: SOVEREIGNTY, INTERNATIONAL JURISDICTION AND ECOLOGICAL INTERVENTION}

\author{
Rafael Lazzarotto Simioni** \\ Eliane Moreira Lorenzet ${ }^{* * *}$
}

\begin{abstract}
Resumo: Conflitos internacionais ligados ao desrespeito ao meio ambiente só passaram a ocorrer recentemente. Dentre as formas para resolução dos conflitos internacionais ambientais temos a ingerência ecológica e a jurisdição internacional, que acabam por ferir o princípio da soberania dos Estados. Mas a globalização e a interdependência cada vez maior dos Estados não mais possibilita a antiga concepção de soberania absoluta. Assim, tornou-se imprescindível a cooperação internacional e o reconhecimento de que o meio ambiente como patrimônio comum da humanidade deve ser preservado por todos, independentemente do Estado ou território ocupado.
\end{abstract}

Palavras-chave: Conflitos internacionais. Jurisdição. Soberania. Ingerência ecológica.

Abstract: International conflicts related to environment disrespect have
begun recently. Among the forms to solve international environmental
conflicts there is ecological intervention and international jurisdiction,
which end up affecting the sovereignty principle of the States. However,
globalization and the increasing interdependency of the States do not
allow the ancient conception of absolute sovereignty. Thus, it is essential
to have international cooperation and recognition that the environment

Pesquisa desenvolvida no âmbito do Projeto "Imputação difusa de responsabilidade ambiental e prevenção cooperativa de riscos ecológicos“, do Grupo de Pesquisa Metamorfose Jurídica - Mestrado em Direito e Departamento de Direito Privado, Centro de Ciências Jurídicas, Universidade de Caxias do Sul.

- Doutorando em direito pela Unisinos, Mestre em Direito pela UCS, Professor e Coordenador do Curso de Direito do Ceulji/Ulbra Ji-Paraná- Rondônia e pesquisador do Grupo de Pesquisa Metamorfose Jurídica (UCS).

Advogada em Guaporé (RS). 
is a common asset of the humanity and that it must be preserved by all men, regardless of the State they live in.

Keywords: International conflicts. Jurisdiction. Sovereignty. Ecological intervention.

\section{INTRODUÇÃO}

Existem atualmente diferentes formas de resolução dos conflitos internacionais ambientais. Dentre essas, as mais discutidas são a ingerência ecológica e a jurisdição internacional. Ambas as propostas, contudo, apresentam problemas no que tange à soberania e a intervenção internacional com relação ao meio ambiente.

No atual momento histórico, se faz imprescindível que a ciência jurídica encontre um meio termo entre defesa da soberania do Estado e a proteção da natureza. As ações do homem podem gerar problemas ecológicos que afetam o ambiente em dimensões espaciais e temporais, muito além das dimensões territoriais de Estado ou do tempo em que vivemos.

Esses conflitos internacionais que surgem em decorrência da irresponsabilidade do homem com seu planeta, poderão ser minimizados significativamente a partir do momento em que o desenvolvimento econômico deixar de ser objetivo primordial de alguns países para dar lugar a uma política voltada ao bem-estar social e a defesa da vida.

Quando as medidas internas de determinado país se tornam ineficazes na resolução de um conflito, este poderá recorrer a uma jurisdição dita jurisdição superior. Mas, até que ponto pode-se interferir na soberania de um Estado com vistas à defesa dos interesses de outros? A existência de uma jurisdição superior é realmente a solução mais adequada para a resolução desses conflitos? É válido optar pela Ingerência Ecológica em detrimento da soberania e em defesa do meio ambiente?

Nessas condições, objetiva-se analisar a relação entre a soberania do Estado e a Ingerência Ecológica, destacando os limites da possibilidade de intervenção ecológica nos conflitos internacionais ambientais.

\section{A SOBERANIA DO ESTADO}

Dentre as inúmeras teorias jurídicas, nenhuma é de tão grande controvérsia quanto à conceituação de soberania. A palavra soberania vem do latim superanus e era utilizada para designar todos os que estivessem no topo de 
uma ordem. Era definida como poder supremo e de ordens incontestáveis (SANTOS, 2007).

$\mathrm{Na}$ Antiguidade, as idéias de superioridade do Estado nada tinham a ver com a noção de supremacia de poder representada pela soberania. De acordo com Dallari, a Antiguidade não chegou a conhecer o conceito de soberania pelo fato de que não havia no mundo antigo "a oposição entre o poder do Estado e os outros poderes”. Foi na Idade Média, com os conflitos decorrentes do surgimento de ordens independentes e das atividades de segurança e de tributação, que o problema passou a ganhar importância (DALLARI, 1987. p. 64).

A teoria jurídica da soberania foi formulada por Jean Bodin. Segundo Dallari (1987, p. 66), vejamos o conceito de soberania estabelecido por Bodin:

Soberania é o poder absoluto e perpétuo de uma República, palavra que se usa tanto em relação aos particulares quanto em relação aos que manipulam todos os negócios de estado de uma República. [...] Sendo um poder absoluto, a soberania não é limitada nem em poder, nem pelo cargo, nem por tempo certo. Nenhuma lei humana, nem as do próprio príncipe, nem as de seus predecessores, podem limitar o poder soberano.

Muito embora Bodin interessava-se pela centralização do poder interno, jamais defendeu a idéia de um poder completamente sem fronteiras. Acreditava que a soberania deveria sujeitar-se ao direito natural e ao direito das gentes. A idéia de poder absoluto de Bodin está ligada à sua crença na necessidade de concentrar o poder totalmente nas mãos do governante; o poder soberano só existe quando o povo se despoja do seu poder soberano e o transfere inteiramente ao governante. Para esse autor, o poder conferido ao soberano é o reflexo do poder divino, e, assim, os súditos devem obediência ao seu soberano (PERINI, 2003).

O conceito de soberania, da forma como surgiu, foi fundamental para que os reis exercessem seu poder, impondo e consolidando sua autoridade sobre determinado povo e território, unificando os Estados (ARIOSI, 2004). Desde então, a soberania passou a ser analisada à luz de seus aspectos internos e externos. Internamente, os soberanos passaram a exercer uma relação de poder com o povo sem intermediários, assumindo um papel de total supremacia não se sujeitando a nenhum outro poder, ou seja, os senhores feudais não tinham mais autonomias locais e todos se sujeitavam ao poder real. Quanto aos aspectos externos da soberania, os soberanos passaram a considerar uns aos outros como iguais, sem a intervenção de nenhum juiz com poder sobre os Estados, cabendo a eles decidir sobre a guerra e a paz. 
Saldanha (2005) afirma que, a soberania, como princípio fundamental do Estado, onde a comunidade aceita e se submete a uma autoridade que a represente, surgiu com a reforma religiosa e tinha por finalidade explicar a existência de um Estado nacional superior, indivisível e independente diante da vontade divina traduzida e exercida então pela Igreja. De acordo com o autor, no início da Idade Moderna, com o aparecimento do mercantilismo e com as disputas pelo poder econômico entre os Estados, a soberania consolidou-se.

Nesse período ocorreu a formação de Estados territoriais soberanos. A formação dos Estados deu origem às relações internacionais a partir da decadência política da igreja e da instrumentalização do direito internacional. O conceito de soberania influenciou diretamente a formação do direito internacional moderno, constituindo-se "no poder incontestado do Estado, sobre o território ocupado pela nação, devendo ambos viver fraternalmente" (MERCADANTE; MAGALHÃES, 1999. p. 439).

O Estado Moderno é titular do poder. Titular de um poder instituição, onde a autoridade não está diretamente associada ao indivíduo que a exerce ${ }^{1}$. A soberania é o elemento essencial para o reconhecimento do Estado como tal, independente de qualquer ato formal que possa existir para que isso ocorra. De acordo com Dallari, só o Estado é que tem soberania e por isso se diferencia das demais pessoas jurídicas de direito internacional público.

Tendo surgido como característica principal do Estado, a soberania, no decorrer da história passou por significativas transformações. Passou de poder absoluto e perpétuo do soberano às mãos do povo por meio de Rousseau, atribuindo-se à burguesia, à nação, para, no século XIX, aparecer como emanação do poder político. Posteriormente, a titularidade do poder soberano passa a ser do Estado. Atualmente, a interdependência dos mesmos direciona cada vez mais a uma interligação entre a idéia de soberania e de cooperação, econômica, jurídica e social.

8 "O poder despersonalizado precisa de um titular: o Estado. Assim, o Estado procede da institucionalização do Poder, sendo que suas condições de existência são o território, a nação, mais potência e autoridade. Esses elementos dão origem à idéia de Estado. $\mathrm{Ou}$ seja, o Estado Moderno deixa de ser patrimonial. Ao contrário da forma estatal medieval, em que os monarcas, marqueses, condes e barões eram donos do território e de tudo o que neles se encontrava (homens e bens), no Estado Moderno passa a haver a identificação absoluta entre Estado e monarca em termos de soberania estatal.” (STRECK; MORAIS, 2000, p. 26). 
Um dos fatores de limitação da soberania é a soberania dos outros Estados. O direito Internacional, de certa forma, contribui para relativizar a soberania do Estado, uma vez que a comunidade internacional confere ao Estado Moderno o dever de observância, acima de seus próprios interesses, aos interesses comuns da humanidade ${ }^{2}$.

Dallari afirma que a ação soberana dos Estados é delimitada pelo território. Considera a ordem jurídica do Estado, por ser a única que tem soberania, a mais eficaz, pois depende dela aceitar ou não a aplicação, dentro dos limites territoriais deste Estado, de normas jurídicas externas. No entanto, o autor pondera que "há casos em que certas normas jurídicas dos Estados [...] atuam além dos limites territoriais, embora sem a possibilidade de concretizar qualquer providência externa sem a permissão de outra soberania" (MERCADANTE; MAGALHÃES, 1999, p. 76). Estes casos, onde as normas de um Estado atuam além dos limites territoriais, tendem a ocorrer nas situações que se referem aos direitos dos indivíduos, como é o caso dos direitos fundamentais do homem, por exemplo.

Embora investido de poder soberano, o Estado deve ser governado com retidão, respeitando as leis naturais, o interesse público e a propriedade. A soberania é limitada pelo direito internacional ou direito das gentes, isto é, pelas leis dos homens que são comuns a todos os povos.

Nas últimas décadas pôde-se perceber uma evolução da concepção de soberania no sentido de que se passou de uma noção de soberania unicamente política para uma noção jurídica do termo. O poder soberano passou a preocupar-se em ser legítimo, em ser jurídico. Segundo essa concepção não há Estados mais fortes ou mais fracos, uma vez que para todos a noção de direito é a mesma. A grande vantagem dessa conceituação jurídica é que mesmo os atos praticados pelos Estados mais fortes podem ser qualificados como antijurídicos, permitindo e favorecendo a reação de todos os demais Estados ((MERCADANTE; MAGALHÃES, 1999).

A soberania, como poder jurídico, passa a figurar nos ordenamentos dos Estados. Em nossa Constituição Federal, o princípio da soberania se encontra resguardado no artigo 1 , I, demonstrando uma idéia de total independência de decisões. Mas com o desenvolvimento tecnológico das últimas décadas

2 "A soberania então só existe quando incontestada, o que só pode ocorrer dentro de um território, e caberia ao direito fazer com que cada Estado pudesse exercer sua própria soberania sem interferir no exercício dos demais.” (MERCADANTE; MAGALHÃES, 1999, p. 439). 
houve uma aceleração no processo de internacionalização. Com as transformações que vem sofrendo o Estado Moderno, a soberania, considerada não só como elemento do Estado, mas como sua razão de ser e de existir na ordem internacional, já não possui mais as características de antigamente.

Após o fim da Segunda Guerra Mundial, as mudanças no sistema internacional ensejaram novos debates em torno das relações internacionais. Baptista e Fonseca, no que diz respeito às relações entre os Estados, acreditam que "Dado essencial do direito internacional é o compromisso entre Estado e sociedade internacional. [...] Podem ocorrer divergências e colidências, mas a interação entre ambas as esferas é inevitável” (BAPTISTA; FONSECA, 1998. p. 288). Contudo, os mesmos autores declaram:

Não obstante tudo o que se publicou a respeito das mutações e possibilidade de reformulação do conceito de soberania - quer como anseio, quer como constatação - o Estado continua sendo o principal sujeito e agente do direito internacional, onde a prática dos Estados, e o conseqüente enquadramento jurídico desta, decorrerão da avaliação que faça cada governo de seus interesses. (BAPTISTA; FONSECA, 1998, p. 288).

Extemporâneo seria subordinar o Estado a imperativos de conduta, porém o movimento de globalização ocorrido nas últimas décadas ocasionou um estreitamento de fronteiras que não mais nos permite viver a concepção de soberania absoluta que nos era apresentada.

Saldanha (2005, p. 301) afirma que o "desenvolvimento da comunidade internacional em um ritmo de interação global, traz consigo um certo enfraquecimento do Estado", flexibilizando o conceito de soberania. "A partir deste momento os Estados passam a dividir as relações de poder com outros entes, conformando um fenômeno de globalização [...] principalmente devido à modificação do entendimento do que seria a soberania estatal”.

A soberania continua sendo a força motriz das relações internacionais, porém com um novo caráter, impossível de ser entendido à luz do direito internacional clássico, que, regulando a prática diplomática, os direitos e as obrigações de beligerantes ou os modos de aquisição de territórios, se limitava tão-somente a dispor sobre a coexistência dos elementos constitutivos de uma totalidade inorgânica. O novo conceito de soberania depende hoje de imperativos fáticos que exigem maior coordenação das diversas partes de uma mesma estrutura orgânica, sob pena de comprometer-lhe irreversivelmente a existência. Em outras palavras, não é mais possível admitir que os Estados 
ajam com total discricionariedade, apenas de acordo com os respectivos interesses nacionais, baseados numa filosofia imediatista, que tolera o desenvolvimento a qualquer preço, sem atentar para o equilíbrio entre atividade econômica e meio ambiente (MERCADANTE; MAGALHÃES, 1999).

Por tudo que se viu acerca da soberania, pôde-se perceber as evoluções em sua aplicação e conceito, antes unicamente político, agora, disciplinado juridicamente. Esse poder soberano jurídico se constitui um importante obstáculo às decisões arbitrárias ou pelo uso da força. pela força. De acordo com Dallari (1987, p. 72), a afirmação de soberania como sinônimo de independência "se apóia no poder de fato que tenha o Estado, de fazer prevalecer sua vontade dentro de seus limites jurisdicionais”. O autor afirma, no entanto, que a conceituação jurídica de soberania "se baseia na igualdade jurídica dos Estados e pressupõe o respeito recíproco, como regra de convivência”. Ademais tudo que se estudou até agora acerca das transformações do conceito de soberania, deve-se observar as mudanças ocorridas no modelo de Estado, que muito tem a ver com as mutações sofridas pela soberania.

A passagem do modelo de estado mínimo ao feitio liberal clássico para o tipo de Estado de bem-estar Social impõe a reconsideração do fenômeno da soberania. [...] O caráter solidário do poder estatal, para muitos, substitui a sua característica soberana para incorporá-lo na batalha cotidiana de superação das desigualdades e de promoção do bem-estar social, percebido como um benefício compartilhado pela humanidade toda (STRECK; MORAIS, 2000, p. 126).

Definitivamente, o caráter soberano atribuído ao Estado deve ser revisto. Não mais se trata da formação de uma ordem absoluta, e sim, da transformação desta. No nível das relações internacionais percebe-se visivelmente a constituição de uma série de compromissos entre os Estados e não de soberania.

\section{JURISDIÇÃO INTERNACIONAL}

No direito interno, a jurisdição está ligada diretamente ao elemento território, e, a competência, delimita o exercício desta jurisdição. Já, no direito internacional, jurisdição e competência se confundem, criando um conceito único. Internacionalmente, os Estados não são subordinados a um ordenamento, o que ocorre é um acordo entre os poderes ${ }^{3}$.

3 “Ao nosso ver, jurisdição internacional é uma prerrogativa estatal atribuída pelo ordenamento internacional que permite aos Estados estender seu controle sobre pessoas, recursos e eventos ocorridos fora de seu território. Depreende-se do "conceito" que as 
O tema da solução de litígios internacionais, principalmente os que dizem respeito a conflitos relacionados aos problemas ecológicos, tem sido um dos mais tradicionais do Direito Internacional. Isso se deve, principalmente, à crescente preocupação dos Estados com a preservação do meio ambiente e às modificações ocorridas nas relações internacionais, tais como inovações acerca do conceito de soberania e a emergência das organizações intergovernamentais.

Com relação ao que se considera litígio internacional, não há até o momento uma conceituação definida. Podemos considerar, então, como conceito de litígio internacional "qualquer controvérsia, originária de conflitos de interesses, de qualquer natureza, entre dois ou mais Estados" (MERCADANTE; MAGALHÃES, 1999, p. 13). Estes conflitos de interesses podem tratar-se tanto de divergências na interpretação de normas internacionais, como também podem estar relacionados a situações de fato, que, por não haver a existência de regulamentação vigente, surja a necessidade de se estabelecer normas que os regule.

Ao se falar em resolução de conflitos internacionais, nos direcionamos especificamente aos mecanismos pacíficos para que se atinja a resolução desses conflitos. Se os Estados resolvessem optar pelo uso indiscriminado da força para alcançar seus ideais, toda a humanidade sairia prejudicada, uma vez que não existe hoje uma ordem superior que possa obrigá-los a agir juridicamente. Talvez tenha sido pelo reconhecimento dessa deficiência que, nos últimos tempos, tantas organizações internacionais dotadas de um órgão de poder tenham sido criadas. Essa inovação modifica profundamente a forma de relacionar-se dos Estados.

Os conflitos internacionais ambientais surgem a partir da reação de um ou mais Estados frente a um dano ao meio ambiente provocado por outro Estado que possa vir a comprometer seriamente a vida no Planeta. Por vezes também, os conflitos internacionais ambientais ocorrem a partir de atitudes de desrespeito a tratados acerca da proteção ambiental firmados por estes Estados ou diante de ações destes que venham a contrariar interesses políticos ou econômicos de determinado país. Nesse contexto, algumas correntes têmse posicionado de forma favorável a uma jurisdição superior que venha a tomar decisões no âmbito internacional no sentido de buscar soluções para estes conflitos ambientais que têm surgido entre os Estados ${ }^{4}$.

regras de exercício de jurisdição internacional do Estado, embora ditadas pelo seu ordenamento interno, são limitadas pela ordem internacional.” (MERCADANTE; MAGALHÃES, 1999, p. 323). 
Atualmente, a escolha dos meios para a solução pacífica de litígios fica a cargo da vontade soberana dos Estados-membros. Estes poderão optar, dentre as várias formas de solução para suas controvérsias, pelo que entenderem ser o melhor para a manutenção da paz e da segurança nacional (SALDANHA, $(2005 \text {, p. } 757)^{5}$.

$\mathrm{Na}$ tentativa de dirimir esses conflitos, conforme Sirvinskas (2002), os Estados vêm criando, por meio de acordos, convenções e normas de proteção ao meio ambiente, um Direito Internacional Ambiental. $\mathrm{O}$ autor conceitua direito internacional ambiental como "o conjunto de regras e princípios que criam obrigações e direitos de natureza ambiental para os Estados, as organizações intergovernamentais e os indivíduos” (SIRVINSKAS, 2002, p. 305).

O direito internacional ambiental nasceu de forma particularmente complexa, oriundo de um processo desordenado que tem sua origem em diferentes fontes, com normas de valores distintos, e superposição de regras tratando do mesmo tema, para as quais cada Estado vota a favor ou contra, inspirandose em lógicas diferentes. (VARELLA, 2003, p. 21).

A Convenção de Viena ${ }^{6}$ sobre o direito dos tratados regulamenta a forma como estes devem ser celebrados, impondo regras para a solução de litígios decorrentes do descumprimento dos mesmos. Hoje, havendo o descumprimento de uma regra ou princípio estabelecido, e na ausência de uma autoridade internacional que tenha competência para fazer cumprir as obrigações assumidas

${ }^{4}$ De acordo com Saldanha (2005, p. 154), o o Direito Internacional atua no sentido de manutenção da ordem e da paz entre os Estados: "O Direito Internacional age no sentido de proporcionar uma ordem na natural anarquia internacional, criando um modelo de conduta dos Estados em suas relações internacionais, buscando estabelecer uma política de apaziguamento, garantindo a segurança de Estados menos poderosos, igualando todos frente a um conjunto de normas internacionais."

5 "As partes em uma controvérsia, que possa vir a constituir uma ameaça à paz e à segurança internacionais", reza o art. 33, §1, da carta da ONU, "procurarão, antes de tudo, chegar a uma solução por negociação, inquérito, mediação, conciliação, arbitragem, solução judicial, recursos a entidades ou acordos regionais, ou a qualquer outro meio pacífico à sua escolha.”

${ }^{6}$ A Convenção de Viena sobre o Direito dos Tratados, adotada em 22 de maio de 1969, codificou o direito internacional referente aos tratados. O projeto de convenção foi preparado pela Comissão de Direito Internacional das Nações Unidas e submetido pela ONU à apreciação da Conferência de Viena sobre o Direito dos Tratados. A Convenção entrou em vigor em 27 de janeiro de 1980. 
pelos Estados, a comunidade internacional, por intermédio da ONU, poderá intervir para que se cumpra o pactuado. A criação de tribunais para julgar ações que afetem a humanidade como um todo vem sendo uma constante desde a Segunda Guerra Mundial. Embora o surgimento de uma forma de jurisdição superior tenha gerado grande polêmica, não há mais discussões acerca da legitimidade dessas instituições.

É importante salientar que a jurisdição internacional é residual e somente se poderá recorrer a ela se a via procedimental doméstica do país vinculado já tiver sido esgotada. Ela só poderá ser instaurada se a jurisdição interna não se mostrar apta para solucionar a contento provável violação aos direitos inerentes a pessoa humana. $\mathrm{O}$ que ocorre é que, sendo a jurisdição uma manifestação de poder, implica ela diretamente com a questão da soberania nacional. Ao aderir a tribunais ou organizações internacionais na tentativa de dirimir algum conflito, primeiramente, o Estado deverá aceitar a jurisdição complementar desses órgãos, abrindo mão, em parte, de sua soberania. Todavia, o Estado possui a prerrogativa de defender a liberdade e a igualdade, características fundamentais da democracia, do Estado Democrático ${ }^{7}$.

Da mesma forma como o princípio da soberania confere poder aos Estados para que exerçam suas funções, os princípios da democracia, quais sejam liberdade e igualdade, garantem que todos os Estados são iguais perante as leis dos homens e de Deus e nenhuma ação unilateral que venha em detrimento dos direitos fundamentais dos homens deixará de ser punida sob alegações como a de independência e de autonomia do Estado. É importante salientar que a democracia é "a única sociedade e o único regime político que considera o conflito legítimo" de modo que ela não só analisa os conflitos de interesses como também "procura instituí-los como direitos" exigindo que sejam reconhecidos e respeitados. Ademais, os indivíduos das sociedades democráticas unem-se em associações e movimentos instituindo um "contrapoder social que [...] limita o poder do Estado” (VARELLA, 2003, p. 97).

As lutas históricas em prol da democracia nos mostram quão duro é alcançála, e muito mais do que isto, conservá-la. É evidente que a questão da democracia nasce lado a lado com o processo de formação da sociedade organizada e do

7 " $\mathrm{Da}$ idéia de que somos - idealmente - iguais, pode-se deduzir que ninguém deve mandar em ninguém. Mas a experiência ensina que, se quisermos ser realmente todos iguais, deveremos deixar-nos comandar. Por isso a ideologia política não renuncia a unir liberdade com igualdade. A síntese desses dois princípios é justamente a característica da democracia." (VARELLA, 2003, p. 27). 
Estado. Para tanto, basta ver [...] o lento processo de conquistas das liberdades e dos direitos humanos. Na tentativa de auxiliar ou forçar os Estados a cumprirem seu papel de Estados Democráticos, garantindo a organização estatal, a aceitação da legitimidade de uma jurisdição internacional com órgãos com competência de julgar e punir ações que venham a tolher ou desrespeitar a liberdade, a igualdade e os direitos humanos mostra-se essencial à concretização da democracia. Para a solução pacífica das controvérsias entre os Estados, como último recurso previsto nos tratados e convenções internacionais, depois de esgotados todos os outros, os Estados podem reportar-se a Corte Internacional de Justiça (VARELLA, 2003, p. 25).

A Corte Internacional de Justiça, com sede em Haia, na Holanda, é o principal órgão judiciário da Organização das Nações Unidas (ONU). Composta por 15 juízes internacionais, eleitos pela Assembléia Geral e pelo Conselho de Segurança para um mandato de 9 anos, a Corte possui funcionamento permanente e pode receber litígios de qualquer dos membros da ONU, ou de qualquer dos países que fazem parte do seu Estatuto, como também litígios movidos por Estados ou em desfavor de Estados que não façam parte da organização (DALLARI, 1987, p. 230).

Recorrer a Corte Internacional de Justiça, nos dias atuais, tem sido um meio indicado após o qual, caso a solução não se apresentar satisfatória para as partes, ainda se admite a utilização da conciliação.

$\mathrm{Na}$ verdade, o recurso à Corte Internacional de Justiça representa uma via de extremo formalismo, em que se discute a aplicação e execução de normas jurídicas preexistentes ao litígio, através de procedimentos igualmente preexistentes, sobre os quais os Estados-partes numa controvérsia não têm qualquer influência no sentido de instituir novas fases, novos prazos ou de modificar uma competência dos julgadores conforme estabelecida entre as Partes numa controvérsia; na verdade, trata-se da interpretação de aplicação do direito, por funcionários internacionais investidos de um poder jurisdicional permanente e independente da vontade "ad hoc" dos Estados-partes numa controvérsia. (MERCADANTE; MAGALHÃES, 1999, p. 38).

A Corte Internacional de Justiça foi instituída no ano de 1946 como um dos cinco órgãos permanentes da ONU. Ela possui uma jurisdição territorial universal e "competência para 'quaisquer casos que as partes lhe submetam e em todas as matérias especialmente contempladas na Carta das Nações Unidas ou em tratados ou convenções em vigor' (art. 36 do Estatuto da CIJ)" (MERCADANTE; MAGALHÃES, 1999, p. 39). O exercício da jurisdição da Corte Internacional de Justiça encontra, como principal problema, o fato de que ela 
não se instala de forma automática, pela vontade de um Estado e contra a vontade de outro. $\mathrm{Na}$ prática, sempre há a necessidade de um compromisso de ambas as partes aceitando a jurisdição da Corte para que a mesma seja acionada. $\mathrm{O}$ simples fato de esta via de solução pacífica de controvérsias estar prevista em tratados e convenções internacionais, não proporciona a um Estado o direito de ativar unilateralmente aquele tribunal.

As vantagens de se recorrer a Corte para a solução de litígios estão na rapidez dos procedimentos, principalmente os acautelatórios, e na segurança das decisões que vêm criando uma jurisprudência em nível internacional ${ }^{8}$.

Um dos temas que mais tem sido objeto de discussões e lides entre Estados são os problemas com a preservação do meio ambiente. A Corte Internacional de Justiça tem sido constantemente acionada em razão desses conflitos. Só pela Nova Zelândia, em um período de 20 anos, a Corte Internacional de Justiça, foi acionada por duas vezes, em 1974 e em 1995, em decorrência dos testes nucleares realizados pela França em áreas do Pacífico Sul. Embora a Nova Zelândia não tenha conseguido a condenação da França, esta sofreu inúmeras críticas de ecologistas do mundo inteiro, que solicitavam, ao menos, a diminuição do número de testes a serem realizados (MERCADANTE; MAGALHÃES, 1999). Argentina e Uruguai também, desde 2006, têm figurado constantemente como parte diante à Corte Internacional de Justiça. Isso porque em maio de 2006 a Argentina protocolou petição junto a Corte alegando supostas violações cometidas pelo Uruguai ao Tratado do Rio Uruguai firmado entre os dois países em fevereiro de 1975. O Tratado estabelece mecanismos para a melhor utilização da parte do Rio que é fronteira entre os países. A divergência entre eles iniciou a partir da autorização pelo Uruguai para a instalação de duas fábricas de celulose no rio. A Argentina apóia-se na alegação de que as fábricas irão prejudicar o meio ambiente poluindo o rio. A Corte, embora não tenha reconhecido o risco iminente levantado pela Argentina de que a instalação das fábricas de celulose possa gerar danos irreparáveis ao meio ambiente, deixou claro que o Uruguai será responsável por qualquer conseqüência danosa ao rio (CAPELLI, 2007).

\footnotetext{
8 "Suas vantagens em relação aos outros meios de soluções de litígios continuam vigentes: a urgência nos procedimentos em geral e naqueles acautelatórios (uma vez que se trata do exercício de funções normais de um órgão composto de julgadores pré-constituídos e de caráter permanente, com normas procedimentais vigentes e sem possibilidade de alterações pelas Partes na controvérsia), e constituir-se uma fonte segura de desenvolvimento de uma jurisprudência relativamente uniforme em Direito Internacional.” (MERCADANTE; MAGALHÃES, 1999, p. 42).
} 
Como se pôde perceber, a Corte Internacional de Justiça desempenha um papel de extrema importância na solução pacífica de controvérsias na esfera internacional, principalmente no âmbito das questões ambientais, cujas divergências se tornam cada vez mais freqüentes, resultado da não preservação dos recursos naturais, já escassos em nosso planeta.

\section{A INGERÊNCIA ECOLÓGICA NA SOLUÇÃO DOS CONFLITOS INTERNACIONAIS AMBIENTAIS}

A palavra ingerência tem por significado intervenção, interferência. Ingerência, no plano internacional, é a possibilidade de intervenção nas questões internas do Estado. Atingindo diretamente "a noção de soberania", e visando proteger os direitos humanos, a ingerência tende a diminuir "a área de atuação do Estado" (BAPTISTA; FONSECA, 1998, p. 359).

$\mathrm{O}$ conceito de direito de ingerência encontra-se juridicamente justificado nos capítulos VI e VII da Carta da ONU e vem sendo amplamente utilizado pelas Nações Unidas desde o início dos anos $90^{9}$. A noção de ingerência entre Estados surgiu no domínio humanitário, única situação em que saiu do simples conceito e desenvolve íatividades, ditas por alguns, nada positivas para a humanidade. E, com as intervenções em nome do direito humanitário praticadas por países como os Estados Unidos, da forma como os acontecimentos internacionais têm ocorrido, chegamos ao extremo de desprezar a existência de um direito humanitário ${ }^{10}$.

Diferentemente da ingerência humanitária, a ingerência ecológica têm muito mais possibilidades de ser efetivada, unicamente pela necessidade do homem

\footnotetext{
9 "Antes, falava-se de um direito de intervenção somente nos casos em que a paz estava ameaçada, e se tratava sobretudo da legítima defesa e da legítima defesa coletiva, previstas pela Carta das Nações Unidas. Gradualmente, o conceito ampliou-se, atingindo outros domínios baseados no direito de assistência humanitária, com uma infinidade de possibilidades, como assistência em casos de catástrofes naturais, catástrofes políticas, construção da democracia, luta contra o terrorismo, chegando hoje a novos conceitos, como o meio ambiente ser considerado um direito do homem ou, ainda, como um valor em si mesmo." (VARELLA, 2003, p. 91).

10 "Mas se este tipo de direito de ingerência, até aqui limitado a um domínio para o qual parecia haver sido concebido, não conseguiu impor-se apesar de seu uso, tão amplo quanto inútil, parece que se perspectiva um novo domínio de intervenção, em virtude da incrível e incomensurável estupidez da espécie humana, que acabou mesmo por comprometer as suas hipóteses de sobrevivência num planeta, o único que lhe permitiu existir até agora." (BACHELET, 1995, p. 269).
} 
em garantir sua própria existência. $\mathrm{O}$ direito de ingerência se impõe diante $\mathrm{da}$ ineficácia do Estado em proteger seu meio ambiente ou de fazer com que seus nacionais o façam. A Ingerência Ecológica é vista por muitos como solução aos conflitos internacionais ambientais e ou como prevenção a futuros problemas ambientais que possam a vir comprometer a vida no planeta ${ }^{11}$.

De acordo com a situação histórica, a noção de soberania é manipulada para atender a diferentes fins, porém nem sempre no sentido de proteger os mesmos seres humanos que formam este estado de riscos como os problemas ecológicos, por exemplo. A tolerância pacífica dos cidadãos diante dos riscos ecológicos mundiais demonstra que o próprio homem não consegue vislumbrar os efeitos gerados pelos seus comportamentos ambientais suicidas, quer porque os Estados manipulam a realidade catastrófica do ambiente, quer porque se ignora o sentido da responsabilidade perante aqueles que virão depois de nós. Em conseqüência, mais que a mobilização dos Estados à volta de ações concretas, que o permitirá definir suas estratégias ambientais, é necessário superar a contradição entre o local e o global para possibilitar a coexistência pacífica das vontades de conquista. A humanidade tem problemas em comum a resolver, por isso, a responsabilidade do homem perante o meio ambiente deve ser encarada pelo ângulo da solidariedade planetária e da harmonia (COLOMBO, 2006).

Bachelet (apud BAPTISTA; FONSECA, 1998, p. 24) afirma que o Estado pode reger as pessoas e os bens que estão em seu território por meio do estabelecimento de normas jurídicas que administram o comportamento das pessoas, porém, mesmo sendo reconhecida esta liberdade de agir do Estado como absoluta, ela esbarra no "contexto do direito internacional e dos costumes respeitados por todas as potências”. O limite da soberania está no direito dos outros. O meio mais adequado para respeitá-lo consiste, especialmente, em proteger o próprio meio ambiente, lembrando, aliás, que não são só as gerações presentes que têm direito ao desenvolvimento (SILVA, 2000, p. 64).

A trajetória histórica dos conflitos entre Estados nos leva a afirmar que soberania e ingerência são dois opostos que se complementam e que sempre

11 "Abandonar, em parte, a ortodoxia da soberania em proveito de uma nova forma de reger o comportamento das relações entre Estados deriva de uma necessidade de organizar a vida internacional em função dos novos fatores que caracterizam essas relações que, decididamente, apenas têm um único meio de existência que sabemos agora ser perecível: a Terra.” (BAPTISTA; FONSECA, 1998, p. 22). 
andaram lado a lado. A sucessão de soberanias e ingerências misturadas com dados sociais, culturais, econômicos é que criaram a história dos Estados. Poderíamos dizer que uma só existe em função da outra. Não se trata de suprimir um instituto jurídico e substituí-lo por outro. Mas no fato de que há várias atitudes estatais possíveis para eliminar os riscos de prejudicar a natureza de forma definitiva se alguns Estados se concretizarem pela omissão de outros ou de operadores econômicos colocados sob sua soberania (BACHELET, 1995, p. 25).

Não havendo um poder supranacional disponível para forçar os Estados a protegerem os direitos fundamentais, a ingerência poderá se constituir num mecanismo comum de proteção do meio ambiente. Outro ponto de sustentação da ingerência está na proteção dos indivíduos acima da nacionalidade, do país do qual ele faça parte. Mesmo porque, o meio ambiente é patrimônio comum da humanidade e os danos ambientais não obedecem aos limites territoriais dos Estados. De fato, a necessidade de agir internacionalmente em prol do meio ambiente impõe-se como um dever e não apenas como um direito. A imposição do respeito pelos direitos do homem na ordem interna de cada Estado carece mais da vontade de utilizar os meios jurídicos disponíveis do que propriamente a ausência destes. E o papel do direito internacional é fazer com que os Estados respeitem as regras que eles próprios declararam primordiais e universais (COLOMBO, 2006, p. 383).

A ingerência pode ser considerada tanto como um direito dos Estados, como também como um dever destes. "Neste sentido, a ingerência é um direito à medida que diante da omissão de um Estado o outro pode dela se socorrer; é um dever porque a responsabilidade pela proteção do meio ambiente é compartilhada" (COLOMBO, 2006, p. 384). Mesmo a ingerência constituindo-se em direito e em dever dos Estados, estes ainda encontram-se temerosos em acolhê-la, pois ela intervém diretamente na soberania estatal e na autonomia de território.

Faz-se importante salientar que não ocorre a ingerência quando a intervenção constar de convenções internacionais ou em tratados, situação em que o que foi pactuado tem força de lei, ou também quando um Estado solicita a assistência de outro ou de agentes internacionais. O elemento definidor da ingerência está na intervenção de um Estado nos assuntos internos de outro, com o fim de proteger os direitos do homem e evitar a concretização de danos ao meio ambiente. Então, estamos no direito de propor, no caso de riscos maiores, uma outra possibilidade de intervenção, a da ingerência, sobretudo em relação aos atos preventivos destinados a impedir a realização 
efetiva de um dano com importantes dimensões físicas e humanas (BACHELET, 1995).

Pioneiro nos estudos acerca da ingerência ecológica, Michel Bachelet, discorre a respeito da possibilidade da intervenção constituir-se num direito de agir mesmo sem o consentimento do Estado afetado. Até aqui, não existe, pois, nenhum direito específico que autorize a intervenção armada unilateral de um Estado noutro, para pôr fim a violações reconhecidas todavia como intoleráveis pela humanidade. "Em compensação, o caráter internacional dos principais riscos ecológicos poderia acelerar a tomada de consciência que é tempo de os Estados fazerem" (BACHELET, 1995, p. 45). O meio ambiente, por ser um problema global, se constitui num domínio que invoca a ingerência. Mesmo assim, a maioria dos doutrinadores não defende explicitamente a ingerência, e sim uma obrigatoriedade da responsabilidade em relação ao meio ambiente, reforçando a idéia de cooperação, de forma a impedir a expansão de uma ingerência militar, a qual poderia ser extremamente negativa para os países mais fracos que acabariam se tornando um alvo constante de intervenções (VARELLA, 2003).

Conforme Bachelet, os Estados nada teriam a temer diante de mecanismos de ingerência, vistos por este como recurso essencial para o desenvolvimento dos mesmos. Não se trata, pois, de ir ao encontro dos interesses de um país, decidindo aquilo que é bom ou mau para o seu desenvolvimento, mas sim de intervir quando o perigo é suficientemente grave em relação aos meios de que ele dispõe para gerir o risco, evitando a sua concretização, ou assegurando o regresso à normalidade quando a catástrofe se produziu (BACHELET, 1995). As catástrofes, antes atribuídas a fatalidades ou à vontade divina, hoje são imputadas ao descomprometimento do homem com a natureza. Infelizmente, para que os Estados venham a se preocupar com alguma questão ambiental é necessário que ocorra alguma tragédia, fazendo grande número de vítimas.

A natureza não suportará por muito tempo ainda a violação dos seus direitos, ela desaparecerá e com ela o seu algoz, o homem, tão pouco respeitador daquilo que o faz viver e, isto, antes que ele tenha tido tempo de se encafuar num foguetão gigante para destruir o resto do universo (BACHELET, 1995). A proteção e a conservação da biosfera e consequentemente dos humanos incumbem tanto ao Estado como aos cidadãos. Ambos encontram-se como gestores e utilizadores, defensores comuns dos interesses ecológicos da coletividade nacional e internacional. Por isso, tanto o Estado como o indivíduo poderão agir para a melhoria das condições ambientais. "O ambiente é, pois, um novo exercício da democracia” (BACHELET, 1995, p. 
73). Doravante, o homem começa a compreender que o seu comportamento ambiental é muito mais perigoso do que imaginava. É chegado o momento de se comprovar mais uma vez a teoria de que para toda ação existe uma reação, e muito embora no meio ambiente as reações às ações do homem não ocorram de forma tão instantâneas, elas são imensuravelmente graves e irreversíveis. A questão do meio ambiente deve ser tratada como um problema de patrimônio comum, por autoridades e jurisdições internacionais ${ }^{12}$.

A concepção de Organizações Internacionais que gerenciem os recursos naturais da Terra se harmoniza plenamente com a necessidade de superar a realidade atual, a fim de modificar a política de desenvolvimento global, que deve ser baseada na idéia de que os recursos da terra e dos oceanos são heranças da humanidade, subordinando a utilização destes recursos naturais à manutenção do bem comum do povo. "Por sua própria natureza, o meio ambiente é um tema que tende a desprezar fronteiras jurídico-políticas dos Estados; assim, as normas internas dos Estados tendem a conformar-se com exigências e padrões internacionais” (GUERRA, 2006, p. 377). Em âmbito internacional, o primeiro grande passo dado para a tutela jurídica do meio ambiente foi por meio da declaração sobre o Ambiente Humano, lançada na Conferência das Nações Unidas para o Meio Ambiente, realizada em Estocolmo em 1972, tendo importância equivalente a Declaração dos Direitos do Homem (BAPTISTA; FONSECA, 1998).

O Brasil sempre esteve na vanguarda das discussões ambientais. A Constituição Brasileira acolheu expressamente aos princípios da Declaração de Estocolmo por meio de seu artigo 225. Também na ECO $92^{13}$, foram lançadas a Declaração do Rio e a Agenda 21, "cujos objetivos principais foram os de criar regras internacionais que assegurassem, no âmbito mundial, a proteção ao meio ambiente", garantindo assim "aos países menos ricos o direito ao desenvolvimento, mas evitando" a "degradação ambiental" (BAPTISTA; FONSECA, 1998, p. 920). A globalização do meio ambiente que

12 "Em conferências internacionais sucessivas se vai dando a identificação das áreas críticas e a identificação inicial com as áreas críticas. [...] Nascem assim a percepção e o reconhecimento do patrimônio comum não excludente universal. [...]. De qualquer forma, está lançada a idéia de que os recursos e riquezas naturais do Leito do Mar e do Fundo dos Oceanos e de seus subsolos além dos limites da jurisdição nacional devem ser declarados herança e patrimônios da Humanidade.” (BAHIA, 1978, p. 172).

${ }^{13}$ Conferência das Nações Unidas sobre o Meio Ambiente realizada no Rio de Janeiro entre 3 e 14 de junho de 1992. 
a Declaração de Estocolmo tinha tentado sistematizar foi consolidada pela Declaração do Rio. Ambas contribuíram significativamente para a conscientização mundial acerca da importância da proteção e preservação do meio ambiente tendo originado um "impressionante desenvolvimento normativo" (GUERRA, 2006, p. 378).

Um dos maiores desafios da sociedade moderna e dos Estados é conciliar a proteção do meio ambiente com o desenvolvimento econômico. E o Direito Internacional Ambiental tem a função de estabelecer mecanismos de controle que possibilitem alcançar um ponto de equilíbrio entre economia e meio ambiente. Neste intuito também são realizadas conferências e criados acordos e tratados internacionais efetivando e defendendo a observação das normas de proteção do ambiente. A partir da análise dos diversos tratados existentes em matéria de Direito Ambiental Internacional, a cooperação internacional é um tema de especial relevância, principalmente porque ações isoladas de um ou de alguns países em defesa do meio ambiente poucos resultados produzirá na contenção de problemas como poluição do ar, contaminação das águas e do solo e extinção de espécies da fauna e flora do planeta.

A cooperação internacional, em matéria ambiental, nada mais é que o reflexo vivo do reconhecimento da "dimensão transfronteiriça e global das atividades degradadoras exercidas no âmbito das jurisdições nacionais”, cujas seqüelas podem alcançar muito além do previsto. Isso significa que o princípio da cooperação internacional reflete as tendências ditadas pelo conjunto da ordem internacional contemporânea, dada a interdependência crescente entre as nações, à procura de um equacionamento e da solução de problemas que transcendem as fronteiras nacionais e a geopolítica tradicional (MILARÉ, 2007, p. 1164). A necessidade de cooperação internacional foi introduzida no ordenamento jurídico brasileiro por meio da inclusão do capítulo VII - Da Cooperação Internacional, na Lei 9605/98 (Lei de Crimes Ambientais). Reza o seu artigo n. 77: "Resguardados a soberania nacional, a ordem pública e os bons costumes, o Governo brasileiro prestará, no que concerne ao meio ambiente, a necessária cooperação a outro país, sem qualquer ônus” (BRASIL, 1998).

Existem hoje inúmeras entidades que atuam internacionalmente no sentido de mobilizar a opinião pública para a necessidade de cooperação entre os Estados. É o caso das ONGs (Organizações não-governamentais), que são um meio "legal de controle popular das relações internacionais travadas entre os Estados, a partir do momento em que as políticas externas passam a ser desenvolvidas e implementadas às claras pelas nações” (MILARÉ, 2004, p. 107). A Agenda 21, principal resultado da ECO 92, dedicou o capítulo número 
27 inteiro "ao fortalecimento do papel das organizações não-governamentais, enquanto parceiros para um desenvolvimento sustentável” (MILARÉ, 2004, p. 108). ${ }^{60}$. Os direitos essenciais do homem não emanam do fato de ele ser nacional de um determinado Estado, mas, sim, por sua condição de pessoa humana. A preservação do meio ambiente como fundamental a garantia de qualidade de vida e dignidade do homem merece proteção que transcende as fronteiras que o cercam.

\section{CONSIDERAÇÕES FINAIS}

Como vimos, existem muitas medidas que os Estados podem tomar para a resolução de conflitos em nível internacional. Quando esgotados ou ineficazes os recursos internos, os Estados poderão recorrer aos Tribunais Internacionais como a Corte Internacional de Justiça. Trata-se de uma via extremamente formal, na qual serão discutidas a existência e a aplicação de normas jurídicas que já existiam anteriormente ao litígio. As decisões tomadas por estes órgãos de jurisdição superior, no entanto, não poderão jamais ser desvinculadas ou antijurídicas. A soberania dos Estados, embora tenha passado por um processo de relativização nas últimas décadas, continua sendo sinônimo de supremacia de poder e de igualdade de direitos. A ingerência ecológica possibilitaria a intervenção nas questões internas dos Estados com o objetivo de defender os interesses da coletividade. Ela implica diretamente na noção de soberania do Estado e possibilita a proteção a direitos do homem tais como o direito a um meio ambiente equilibrado e à qualidade de vida.

As possibilidades de a ingerência ecológica ser efetivada são grandes e isso resulta da necessidade do homem em garantir a sua existência. Muito se tem falado em internacionalização dos problemas ecológicos e muitos esforços para a conscientização acerca da importância da preservação e da cooperação entre os povos têm sido feitos por órgãos como a ONU e as ONGs. O reconhecimento da importância da cooperação internacional significa também o reconhecimento de que as atividades degradadoras do meio ambiente possuem dimensões além das fronteiras dos Estados, o que justificaria a prática da Ingerência Ecológica.

A vida na Terra encontra-se seriamente ameaçada e qualquer instrumento que auxilie na preservação do meio em que vivemos, desde que de forma pacífica e ponderada, deve ser acolhido e empregado. Qualquer atividade lesiva à natureza, independentemente do território ou Estado que esteja ocorrendo, deve ser reprimida. E o Estado possui o dever de implementar políticas de meio ambiente que observem os princípios do desenvolvimento 
sustentável e da proteção das riquezas naturais e do meio ambiente, educar e conscientizar a população nesse sentido, fiscalizando e punindo quando necessário. Aos homens, destruidores de si próprios, para que não dificultem a sobrevivência das gerações futuras, uma só medida se faz necessária: a adoção de uma postura de responsabilidade pela vida.

\section{REFERENNCIAS}

ALMEIDA, Nuno Ramos de. As migalhas dos milhões. Disponível em: <http:/ /www.be-global.org/global/GLOBAL6_G8_0507.htm>. Acesso em: 20 maio 2007.

ARIOSI, Mariângela F. Direito Internacional e soberania nacional. Jus Navigandi, Teresina, ano 9, n. 498, 17 nov. 2004. Disponível em: <http:// jus2.uol.com.br/doutrina/texto.asp?id=5942>. Acesso em: 4 ago. 2007.

BACHELET, Michel. Ingerência ecológica: direito ambiental em questão. Lisboa: Instituto Piaget, 1995.

BAHIA, Luiz Alberto. Soberania, guerra e paz. Rio de Janeiro: Zahar Editores, 1978.

BAPTISTA, Luiz Olavo; FONSECA, José Roberto F. da. O Direito Internacional no Terceiro Milênio. São Paulo: LTr, 1998.

BRASIL. Lei n 9.605, de 12 de fevereiro de 1998. Dispõe sobre as sanções penais e administrativas derivadas de condutas e atividades lesivas ao meio ambiente, e dá outras providências. Diário oficial [da República Federativa do Brasil], Brasília, DF, 13 fev. 1998.

CAPELLI, Sílvia. Corte Internacional de Justiça não acolhe ação cautelar proposta pela Argentina contra o Uruguai no caso das fábricas de celulose no Rio Uruguai. Disponível em: http://www.mp.rs.gov.br/atuacaomp/noticias/ id8405.htm. Acesso em: 27 setembro 2007.

COLOMBO, Silvana. O Direito de Ingerência. In: ESTUDOS de Direito Internacional: anais do 4 Congresso Brasileiro de Direito Internacional. Curitiba: Juruá, 2006. v. 8.

CORREAA, Darcísio; BACKES, Elton Gilberto. Desenvolvimento sustentável: em busca de novos fundamentos. In: SPAREMBERGER, Raquel Fabiana Lopes; PAVIANI, Jayme (Org.). Direito Ambiental: um olhar para a cidadania e sustentabilidade planetária. Caxias do Sul: Educs, 2006. 
DALlARI, Dalmo de Abreu. Elementos de Teoria Geral do Estado. 13. ed. São Paulo: Saraiva, 1987.

FREITAS, Vladimir Passos de. Direito Ambiental em Evolução. Curitiba: Juruá, 2002. v.2

GUERRA, Sidney. A "Globalização" do Meio Ambiente. In: ESTUDOS de Direito Internacional: anais do 4 Congresso Brasileiro de Direito Internacional. Curitiba: Juruá, 2006.

MERCADANTE, Araminta de Azevedo; MAGALHÃES, José Carlos de. Solução e Prevenção de Litígios Internacionais. São Paulo: Necin-Capes; Porto Alegre: Livraria do Advogado, 1999. v. 2.

MILARÉ, Edis. Direito do Ambiente: doutrina, jurisprudência, glossário. 5. ed. rev., atual. e ampl. São Paulo: Ed. Revista dos Tribunais, 2007.

MILARÉ, Edis; LOURES, Flavia Tavares Rocha. O Papel do Terceiro Setor na proteção jurídica do ambiente. Revista de Direito Ambiental, São Paulo, n 35, p. 96-122, 2004.

PERINI, Raquel Fratantonio. A soberania e o mundo globalizado. Jus Navigandi, Teresina, ano 7, n. 76, 17 set. 2003. Disponível em: http:// jus2.uol.com.br/doutrina/texto.asp?id=4325>. Acesso em: 4 ago. 2007.

SALDANHA, Eduardo. Teoria das Relações Internacionais. Curitiba: Juruá, 2005.

SANTILLI, Marcio. Clima e florestas: é hora de avançar. Disponível em: <http:/ /www.socioambiental.org/nsa/direto/direto_html?codigo=2007-05-16-191100>. Acesso em: 20 maio 2007.

SANTOS, Antônio Silveira Ribeiro dos. Redefinição de Soberania. Disponível em: 〈http://www.aultimaarcadenoe.com/redefinicaosoberania.htm>. Acesso em: 14 abril 2007.

SILVA, José Afonso da. Direito Ambiental Constitucional. 3. ed. rev. e atual. São Paulo: Malheiros, 2000.

SIRVINSKAS, Luis Paulo. Manual de Direito Ambiental. São Paulo: Saraiva, 2002.

STRECK, Lenio Luiz; MORAIS, José Luis Bolzan de. Ciência Política e Teoria Geral do Estado. Porto Alegre: Livraria do Advogado, 2000.

VARELLA, Marcelo Dias. Direito Internacional Econômico Ambiental. Belo Horizonte: Del Rey, 2003. 